\title{
Integration of Technology Readiness Index (TRI) Into the Technology Acceptance Model (TAM) for Explaining Behavior in Adoption of BIM
}

\author{
Yin Ling Lai ${ }^{1} \&$ Joseph Lee ${ }^{2}$ \\ ${ }^{1}$ Faculty of Engineering and Quantity Surveying, INTI International University, Malaysia \\ ${ }^{2}$ Faculty of Business, Communication and Law, INTI International University, Malaysia \\ Correspondence: Yin Ling Lai, Faculty of Engineering and Quantity Surveying, INTI International University, \\ Malaysia. Tel: 60-6-798-2000.
}

Received: August 21, 2020

Accepted: October 19, 2020

Online Published: October 26, 2020

doi:10.20849/aes.v5i2.816

URL: https://doi.org/10.20849/aes.v5i2.816

\begin{abstract}
Recently, Building Information Modelling (BIM) technology has attracted much attention in the Architecture, Engineering and Construction (AEC) industry and is becoming globally-recognized standards. The primary objective of this study is to gain better understanding of the drivers and barriers to the adoption of BIM.

There is abundance of theories on technology adoption among which this study applies the Technology Acceptance Model (TAM) proposed by Davis (1989) to analyze the adoption and the use of the BIM technology by exploring implications of perceived ease of use, perceived usefulness, attitudes, behavioral intention and actual usage. In addition, this study integrates Technology Readiness Index (TRI) to explain adoption of BIM.

With data collected through an online survey, findings of this study will assist in explaining behavior in adoption of BIM that may facilitate realizing the advantages of the BIM technology.
\end{abstract}

Keywords: Building Information Modelling (BIM), Technology Acceptance Model (TAM), Technology Readiness Index (TRI)

\section{Introduction}

In recent decades technological advancements has become an integral part of modern life and identify the determinants of adoption of innovations is gaining interests in academia and industry.

Building Information Modelling (BIM) is an intelligent model-based design process that uses reuses and exchanges information with digital documents on a single platform. The implementation of BIM technology has emerged as a mean to escalate productivities in the Architecture, Engineering and Construction (AEC) industry.

While BIM technology and their increasing application are expected to bring some deep changes in AEC industry, it is still unclear how BIM could be used and what the benefits are. (Lee, Yu \& Jeong, 2013).To advance these issues, Song et al. (2016) investigated the factors affecting BIM adoption with TOE \& RC framework. Based on the Technology Acceptance Model (TAM), Merschbrock \& Nordahl-Rolfsen. (2016) set out to answer the question: Will BIM technology be accepted or rejected? Wang, Xue \& Li (2013) focused on understanding the impact factors of BIM acceptance and degrees of influence by applying TAM and relevant theories. Likewise, Gong et al. (2019) proposed a research model of the acceptance of BIM based on a literature review of various technology acceptance theories and, through empirical evidence, provided implications to the challenge of developing a technology-intensive construction industry.

\section{Literature Review}

A variety of theories and models have been developed to investigate the individual acceptance behavior on information including the Theory of Reasoned action (TRA), Theory of planned behavior (TPB), Technology Acceptance Model (TAM) and Unified Theory of Acceptance and Use of Technology (UTAUT).

\subsection{Technology Acceptance Model (TAM)}

The Technology Acceptance Model (TAM) developed by Davis (1989) was derived from the Theory of Reasoned Action (TRA), a psychological theory that seeks to explain people's actions by identifying the causal 
connections between various components: beliefs, attitudes, intentions and behaviors. TAM is one of the most influential models widely used in the studies of the determinant for user acceptance and usage behavior of information technology because it has been effective in the modeling of acceptance of IT and has received extensive empirical support through the studies predicting the use of information systems.

According to TAM, information system usage behavior is predominately explained by behavioral intention that is formed as a result of conscious decision-making processes. Behavioral intention, in turn, is determined by two belief factors:

- $\quad$ Perceived usefulness (PU) - PU is defined as "the degree to which a person believes that using a particular system would enhance his or her job performance"

- $\quad$ Perceived ease-of-use (PEOU) - PEOU is demonstrated as "the degree to which a person believes that using a particular system would be free from effort"

By manipulating these two factors, system developers can have better control over users' beliefs about the system, and subsequently, their attitudes towards usage, behavioral intention and usage of the system.

Since its inception, TAM has been widely used to scrutinize individual technology acceptance behavior in various types of information systems and been applied extensively for different technologies, under different situations with different control factors and in different contexts which has led to extensions and changes in the original model. For example, Mohammad Abu-Dalbouh (2013) utilized a quantitative approach based on TAM to evaluate the user acceptance of mobile technology application within healthcare industry, Shroff, Deneen, \& $\mathrm{Ng}$ (2011) examined whether TAM could legitimately be applied in determining the relationship of students' intention to use an e-portfolio system while the result of Park (2009) proved TAM to be a good theoretical tool to understand users' acceptance of e-learning and, in another study, Alsamydai (2019) adapted TAM with additional dimension of quality factors and experience to understand the use of mobile banking services.

However, perception of the technical features of an innovation may not be sufficient to cover all aspects which would potentially affect users' intention to use and actual usage; as such, a more thorough understanding of acceptance and adoption needs to take additional factors into account.

\subsection{Technology Readiness Index (TRI)}

The growth of highly sophisticated technological products has resulted in fundamental transformations in the interaction with users which indicates attention to the readiness of people is needed. A model that considers individual differences is Technology Readiness Index (TRI) which is defined as the individual's general opinion about technology (Parasuraman, 2000) and describes individual's propensity to embrace and use new technologies. Parasuraman and Colby (2001) segment the Technology Readiness construct into four variables: optimism, innovativeness, discomfort and insecurity of which the first two refer to action enablers, while the other two refer to the inhibitors.

Studies of Parasuraman's (2000) technology-readiness concept are widespread and some studies examine the relationships between technology readiness and technology acceptance. Erdoğmus \& Esen (2011) revealed that four types of technology readiness have different effects on perceived usefulness and perceived ease of use about e-HRM. Başgöze (2015) integrated technology readiness (TR) into the technology acceptance model (TAM) in the context of consumer adoption of mobile shopping (m-shopping) and theorizes that the impact of TR on mobile shopping intention is mediated by both perceptions of usefulness and ease of use. Buyle et al. (2018) considered the relationship between individual characteristics of decision makers and their intention to use data standards and indicate that respondents who score high on innovativeness have a higher intention to use data standards.

\section{Research Design}

\subsection{Research Model}

In accordance with the research objective and consistent with the related literature, the research model, as shown in Figure 1, is based mainly on the Technology Acceptance Model (TAM) presented by (Davis 1989) with additional considerations of the Technology Readiness Index (TRI) proposed by Parasuraman (2000). The proposed model consists of the core constructs of both TAM and TRI and is largely similar to Pires, Filho, \& Cunha (2011) in a study assessing critical aspects of consumer use and acceptance of technology-based products and services and Larasiti, Widyawan \& Santosa (2017) in a model combining dimensions of both TAM and TRI. 


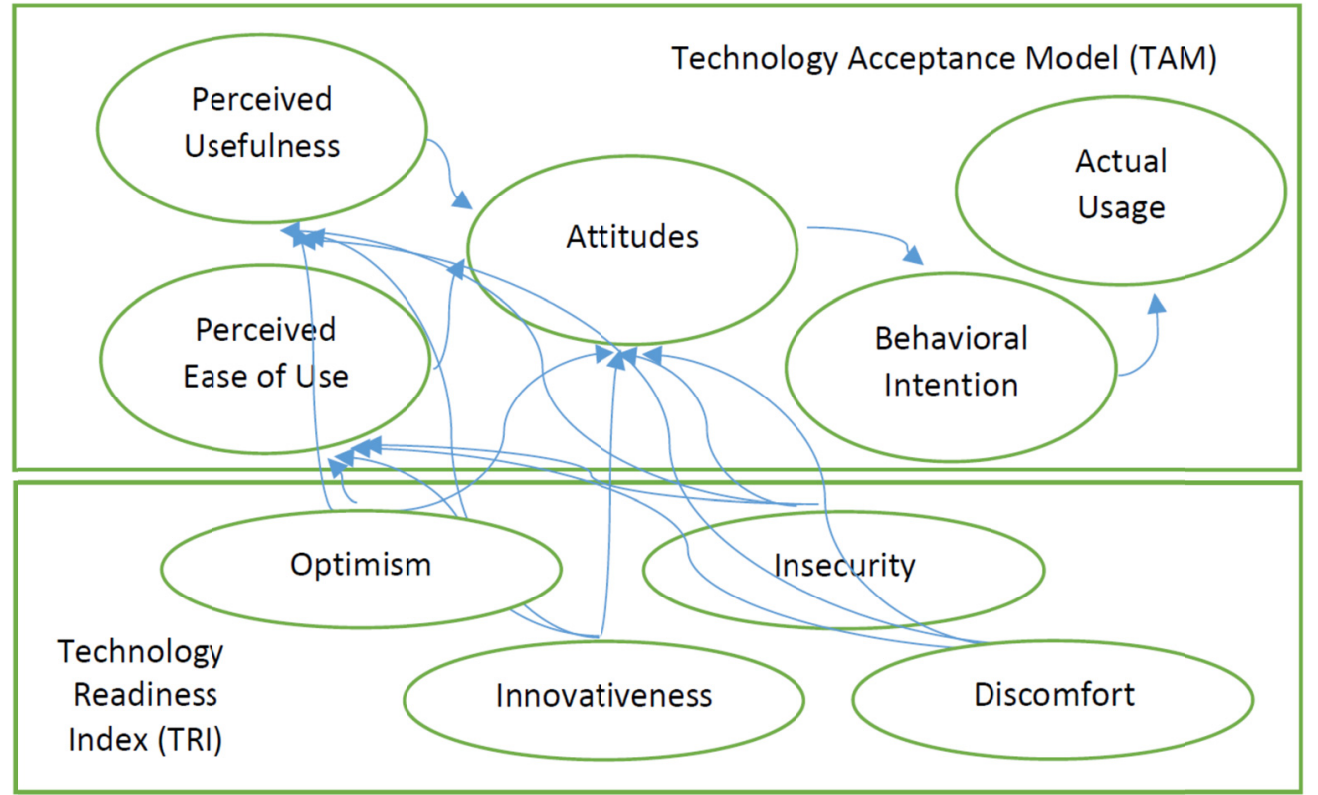

Figure 1. Proposed Research Model

\subsection{Research Instrument}

The research instrument of the present study consists of three main sections. The first section is to identify respondents' demographic information. The second and third section use 5-point Liker response scale where 1: Strongly disagree, 2: Slightly disagree, 3: Neutral, 4: Slightly agree, and 5: Strongly agree on constructs of TAM and TRI, respectively.

As shown in Table 1, there are 28 items measured in accordance with the current study's research model. The measured items include perceived ease of use (6 items), perceived usefulness (6 items), attitude toward usage (3items), and behavioral intention to use (3 items) of the Technology Acceptance Model (TAM) and four dimensions: optimism ( 2 items), innovativeness ( 3 items), insecurity (3 items) and discomfort ( 2 items) of the Technology Readiness Index (TRI).

Table 1. Questionnaire

\begin{tabular}{ll}
\hline Section I Demographic Information & \\
\hline Gender & Male/Female \\
\hline I use BIM frequently & ACTUAL USE \\
\hline Section II TAM Constructs & PEOU \\
\hline I think it does not take a lot of effort to know how BIM work & PEOU \\
\hline I think learning to use BIM is easy for me & PEOU \\
\hline I think finding what I need with BIM is easy & PEOU \\
\hline I think becoming skillful at using BIM is easy & PEOU \\
\hline I think BIM is easy to understand & PEOU \\
\hline Overall, I find the use of BIM easy & PU \\
\hline Using BIM would improve my performance in retrieving information & PU \\
\hline Using BIM would increase clarity in presenting an idea & PU \\
\hline Using BIM would enable me to accomplish my tasks more quickly & PU \\
\hline Using BIM would enhance my effectiveness in illustrating my thinking &
\end{tabular}




\begin{tabular}{ll}
\hline Using BIM would make it easier in communicating with others & PU \\
\hline Overall, I find BIM useful & PU \\
\hline Learning BIM is a good idea & ATU \\
\hline Working with BIM is a wise idea & ATU \\
\hline Overall, I am positive toward BIM & ATU \\
\hline Assuming I had access to BIM, I intend to use it & INTEN \\
\hline Using BIM for handling my tasks is something I would do & INTEN \\
\hline I would see myself using the BIM regularly & INTEN \\
\hline Section III TRI Constructs & OPTI \\
\hline You find new technologies to be mentally stimulating & INSE \\
\hline $\begin{array}{l}\text { If you provide information to a machine or over the Internet, you can never be sure } \\
\text { it really gets to the right place }\end{array}$ & OPTI \\
\hline $\begin{array}{l}\text { You like computer programs that allow you to tailor things to fit your own needs. } \\
\text { You do not consider it safe to do any kind of financial business online }\end{array}$ & INSE \\
\hline $\begin{array}{l}\text { Other people come to you for advice on new technologies } \\
\text { You worry that information you send over the Internet will be seen by other people }\end{array}$ & INSE \\
\hline $\begin{array}{l}\text { You can usually figure out new high-tech products and services without help from } \\
\text { others }\end{array}$ & INNO \\
\hline $\begin{array}{l}\text { When you get technical support from a provider of a high-tech product or service, } \\
\text { you sometimes feel as if you are being taken advantage of by someone who knows } \\
\text { more than you do }\end{array}$ & DISC \\
\hline $\begin{array}{l}\text { In general, you are among the first in your circle of friends to acquire new } \\
\text { technology when it appears }\end{array}$ & INNO \\
\hline $\begin{array}{l}\text { It is embarrassing when you have trouble with a high-tech gadget while people are } \\
\text { watching }\end{array}$ & DISC \\
\hline
\end{tabular}

\section{Data Analysis}

The present study investigates the applicability of using TAM and TRI on two groups: a user group and a non-user group based on their answers to the question "I use BIM frequently?" The survey sample includes 63 respondents of which $26(41 \%)$ use BIM frequently and 37 (59\%) are non-users. The following table illustrates the gender difference of users and non-users of BIM. The relationship among the variables was analyzed by means of the chi-square independence test.

Table 2. Difference in actual usage of BIM by gender

\begin{tabular}{lllllll}
\hline & User & \multicolumn{7}{l}{ Non-User } \\
\hline Gender & $\mathrm{n}$ & $\%$ & $\mathrm{n}$ & $\%$ & Chi Square & Sig \\
\hline Male & 18 & 28.6 & 16 & 25.4 & 4.151 & $0.0416^{*}$ \\
\hline Female & 8 & 12.7 & 21 & 33.3 & & \\
\hline Note: & $* *$ & p-value $<0$ & $.01, *<0.05$ & & & \\
\hline
\end{tabular}

In this case $\mathrm{p}<0.05$, so this result indicates gender is linked to the actual usage which is consistent with the prior research that suggests demographic factors such as gender influence acceptance of information technologies (Venkatesh et al., 2012).

To gain better understanding and validate the data, the following table shows the descriptive statistics and correlation analysis of the TAM constructs. The results clearly support the original hypothesis made in the 
literature concerning TAM as there are significant positive relationships among elements of TAM at level 0.01 .

Table 3. Difference in actual usage of BIM by gender

\begin{tabular}{lllllll}
\hline Constructs & Mean & Std & PEOU & PU & ATU & INTEN \\
\hline PEOU & 3.49 & 0.9249 & 1 & & & \\
\hline PU & 4.12 & 0.7998 & $0.41^{* *}$ & 1 & & \\
\hline ATU & 4.35 & 0.7897 & $0.41^{* *}$ & $0.75^{* *}$ & 1 & \\
\hline INTEN & 4.10 & 0.8477 & $0.33^{* *}$ & $0.61^{* *}$ & $0.57^{* *}$ & 1 \\
\hline
\end{tabular}

Note: $* *$ p-value $<0.01, *<0.05$

The follow figure shows consistent patterns in the various constructs of TAM between the two groups of respondents in the sample: the user vs. non-user which demonstrates and support prior research that PEOU and PU have significant influence on the adoption of BIM.

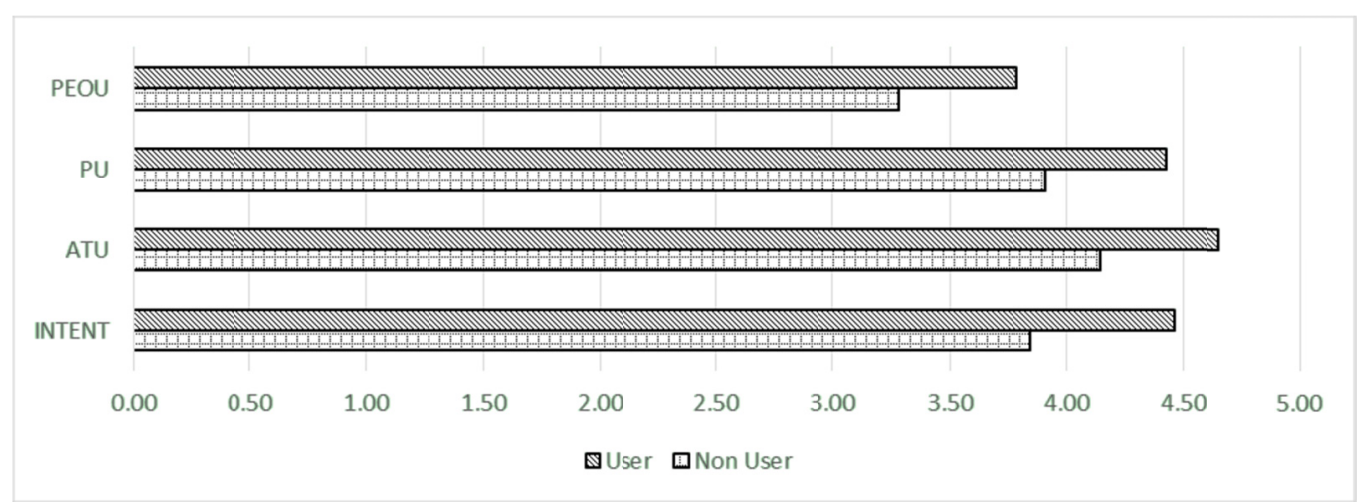

Figure 2. Constructs of TAM: User vs. non-user groups

To study the impacts on actual usage in relation to the constructs of TAM and TRI, respectively, $t$-Test was adopted to compare the mean scores of differences between user and non-user groups.

Table 4. T-test result for adoption

\begin{tabular}{lllllll}
\hline Constructs & User $(\mathrm{n}=26)$ & \multicolumn{5}{l}{ Non User $(\mathrm{n}=37)$} \\
\hline PEOU & Mean & Std & Mean & Std & $t$ & $P$ \\
\hline PU & 3.79 & 0.9572 & 3.28 & 0.8432 & -2.235 & $0.0291^{*}$ \\
\hline INTEN & 3.43 & 0.6437 & 3.91 & 0.8299 & -2.677 & $0.0095^{* *}$ \\
\hline ATU & 4.65 & 0.9165 & 4.46 & 0.5742 & 3.247 & $0.0019^{* *}$ \\
\hline OPTI & 4.13 & 0.4788 & 4.14 & 0.8652 & -2.723 & $0.0084^{* *}$ \\
\hline INSE & 3.40 & 0.6868 & 4.14 & 0.7085 & 0.056 & 0.9556 \\
\hline INNO & 3.64 & 0.9531 & 3.14 & 0.9615 & -2.039 & $0.0458^{*}$ \\
\hline DISC & 3.10 & 1.1591 & 2.97 & 1.1223 & -0.447 & 0.6568 \\
\hline Note: $* *$ p-value $<0.01, *<0.05$ & & & & -0.829 & 0.4103 \\
\hline
\end{tabular}

The results show that elements of TAM contribute significantly in explaining and predicting the actual usage of BIM between user and non-user groups. However, optimism, discomfort and insecurity dimensions of TRI have 
not influenced the adoption. Conversely, the innovative characteristic of individuals is found to impact the adoption of BIM which concurs with previous studies that Innovative individuals are eager to learn new technologies which increases their technology acceptance rate (Turan, Tunc, \& Zehir, 2015) and willingness to try out new information technologies is a very important determinant of use decisions (Ngafeeson \& Sun, 2015).

It is worth noting the outcomes of the present study support some other studies pertaining to the relationships between the various constructs of TRI and perceived usefulness (PU), perceived ease-of-use (PEOU) and attitudes towards usage (ATU) of TAM. As indicated in the following table, similar outcomes were observed as suggested by Erdoğmuş and Esen (2011) that optimism and innovativeness of the TRI constructs are positively related with usefulness and ease of use of the TAM constructs and in Shih and Fan (2013) that optimism has a significant effect on the attitude dimension of TAM.

Table 5. Correlation between constructs of TAM and TRI

\begin{tabular}{|c|c|c|c|c|}
\hline & & $\begin{array}{l}\text { Overall, I find } \\
\text { the use of BIM } \\
\text { easy (PEOU) }\end{array}$ & $\begin{array}{l}\text { Overall, I find } \\
\text { BIM useful } \\
\text { (PU) }\end{array}$ & $\begin{array}{l}\text { Overall, I am } \\
\text { positive } \\
\text { toward BIM } \\
\text { (ATU) }\end{array}$ \\
\hline OPTI & $\begin{array}{l}\text { You find new technologies to be mentally } \\
\text { stimulating }\end{array}$ & 0.23 & $0.36^{* *}$ & $0.41 * *$ \\
\hline OPTI & $\begin{array}{l}\text { You like computer programs that allow you } \\
\text { to tailor things to fit your own needs }\end{array}$ & $0.26^{*}$ & $0.32 * *$ & $0.41 * *$ \\
\hline INSE & $\begin{array}{l}\text { If you provide information to a machine or } \\
\text { over the Internet, you can never be sure it } \\
\text { really gets to the right place }\end{array}$ & 0.08 & -0.02 & 0.01 \\
\hline INSE & $\begin{array}{l}\text { You do not consider it safe to do any kind of } \\
\text { financial business online }\end{array}$ & 0.15 & 0.15 & 0.01 \\
\hline INSE & $\begin{array}{l}\text { You worry that information you send over } \\
\text { the Internet will be seen by other people }\end{array}$ & 0.20 & 0.11 & 0.15 \\
\hline INNO & $\begin{array}{l}\text { Other people come to you for advice on new } \\
\text { technologies }\end{array}$ & $0.46^{* *}$ & $0.30 *$ & $0.41 * *$ \\
\hline INNO & $\begin{array}{l}\text { You can usually figure out new high-tech } \\
\text { products and services without help from } \\
\text { others }\end{array}$ & $0.38 * *$ & 0.13 & 0.25 \\
\hline INNO & $\begin{array}{l}\text { In general, you are among the first in your } \\
\text { circle of friends to acquire new technology } \\
\text { when it appears }\end{array}$ & $0.58 * *$ & 0.09 & 0.19 \\
\hline DISC & $\begin{array}{l}\text { When you get technical support from a } \\
\text { provider of a high-tech product or service, } \\
\text { you sometimes feel as if you are being taken } \\
\text { advantage of by someone who knows more } \\
\text { than you do }\end{array}$ & 0.21 & 0.00 & 0.07 \\
\hline DISC & $\begin{array}{l}\text { It is embarrassing when you have trouble } \\
\text { with a high-tech gadget while people are } \\
\text { watching }\end{array}$ & $0.39 * *$ & 0.13 & 0.19 \\
\hline
\end{tabular}

\section{Conclusion}

This study identified the distinctions between the users and non-users of BIM and confirmed that elements of TAM contribute significantly in explaining and predicting the actual usage of BIM. However, optimism, discomfort and insecurity dimensions of TRI have not influenced the adoption while the innovative characteristic 
of individuals is found to impact the adoption of BIM. Nevertheless, positive relationships were observed between the optimism and innovativeness of TRI and perceived usefulness, perceived ease-of-use and attitudes towards usage of TAM.

Though carefully planned and conducted, this study is not without limitations. Firstly, the generalizability of the findings might be limited due to the sampling procedure, sample size, and diversity in background of respondents. Another limitation of the present study is that it did not attempt to investigate the influences of any external factors. As such, for example, future investigations could build upon the findings of the present study by looking at roles affecting BIM acceptance from an individual and organizational perspective by including some characteristics of the organization, such as, for example, the innovativeness, willingness, technical support and determination of the organization to implement BIM.

Further studies are necessary to better understand user experience with BIM, especially as such research may not only bring economic returns to the users but also contribute to the realization of the advantages of the BIM technology in the Architecture, Engineering and Construction industry. Aspects such as factors affecting individual willingness to use BIM and the role of an organization could be interesting topics for future research.

\section{References}

Başgöze, P. (2015). Integration of Technology Readiness (TR) into the Technology Acceptance Model (TAM) for M-Shopping. International Journal of Scientific Research and Innovative Technology, 2(3), 26-35.

Buyle, R., Van Compernolle, M., Vlassenroot, E., Vanlishout, Z., Mechant, P., \& Mannens, E. (2018). "Technology Readiness and Acceptance Model" as a Predictor for the Use Intention of Data Standards in Smart Cities. Media and Communication, 6(4), 127-139. https://doi.org/10.17645/mac.v6i4.1679

Davis, F. D. (1989). Perceived Usefulness, Perceived Ease of Use, and User Acceptance of Information Technology. MIS Quarterly, 13(3), 319-341. https://doi.org/10.2307/249008

Erdoğmus, N., \& Esen, M. (2011). An Investigation of the Effects of Technology Readiness on Technology Acceptance in e-HRM. Procedia Social and Behavioral Sciences, 24, 487-495. https://doi.org/10.1016/j.sbspro.2011.09.131

Gong, P., Zeng, N., Ye, K., \& Koenig, M. D. (2019). An Empirical Study on the Acceptance of 4D BIM in EPC Projects in China. Sustainability, 11(5), 13-16. https://doi.org/10.3390/su11051316

Hussain, M. A.-D. (2013). A Questionnaire Approach Based on the Technology Acceptance Model for Mobile Tracking on Patient Progress Applications. Journal of Computer Science, 9, 763-770. https://doi.org/10.3844/jessp.2013.763.770

Lee, S. K., Yu, J. H., \& Jeong, H. S. (2013). BIM Acceptance Model in Construction Organizations. Journal of Management in Engineering, 31(3), 1-13. https://doi.org/10.1061/(ASCE)ME.1943-5479.0000252

Mahmood, A. (2014). Adaptation of the Technology Acceptance Model (TAM) to the Use of Mobile Banking Services. International Review of Management and Business Research, 3(4), 2016-2028.

Merschbrock, C., \& Nordahl-Rolfsen, C. (2016). BIM Technology Acceptance among Reinforcement Workers the Case of Oslo Airport's Terminal 2. Journal of Information Technology in Construction, 21, 1-12. Retrieved from http://hdl.handle.net/10642/3246

Ngafeeson, M. N., \& Sun, J. (2015). The Effects of Technology Innovativeness and System Exposure on Student Acceptance of E-Textbooks. Journal of Information Technology Education: Research, 14, 55-71. https://doi.org/10.28945/2101

Parasuraman, A. (2000). Technology Readiness Index (TRI) A Multiple-Item Scale to Measure Readiness to Embrace New Technologies. Journal of Service Research, 2(4), 307-320. https://doi.org/10.1177/109467050024001

Parasuraman, A., \& Colby, C. L. (2001). Techno-Ready Marketing: How and Why Your Customers Adopt Technology. New York: The Free Press.

Park, S. Y. (2009). An Analysis of the Technology Acceptance Model in Understanding University Students' Behavioral Intention to Use e-Learning. Educational Technology \& Society, 12(3), 150-162. Retrieved August 31, 2020, from http://www.jstor.org/stable/jeductechsoci.12.3.150

Pires, P. J., Filho, B. A., \& Cunha, J. C. (2011). Technology Readiness Index (TRI) Factors as Differentiating Elements between Users and Non Users of Internet Banking, and as Antecedents of the Technology Acceptance Model (TAM). In M. M. Cruz-Cunha, J. Varajão, P. Powell, \& R. Martinho (Eds.), 
Communications in Computer and Information Science (Vol. 220). Springer, Berlin, Heidelberg. https://doi.org/10.1007/978-3-642-24355-4_23

Shih, Y. C., \& Fan, S. T. (2013). Adoption of Instant Messaging by Travel Agency Workers in Taiwan: Integrating Technology Readiness with the Theory of Planned Behavior. International Journal of Business and Information, 8, 120-136.

Shroff, R. H., Deneen, C. D., \& Ng, M. W. (2011). Analysis of the Technology Acceptance Model in Examining Students' Behavioral Intention to Use an E-Portfolio System. Australasian Journal of Educational Technology, 27(4), 600-618. https://doi.org/10.14742/ajet.940

Song, J., Wang, G. B., Liu, Z. W., \& Wang, H. C. (2016). Key Factors Affecting BIM Adoption in China Based on TOE\&RC. International Conference on Mechanics, Materials and Structural Engineering, 2016. https://doi.org/10.2991/icmmse-16.2016.40

Turan, A., Tunç, A. Ö., \& Zehir, C. (2015). A Theoretical Model Proposal: Personal Innovativeness and User Involvement as Antecedents of Unified Theory of Acceptance and Use of Technology. Procedia-Social and Behavioral Sciences, 210, 43-51. https://doi.org/10.1016/j.sbspro.2015.11.327

Venkatesh, V., Thong, J. Y., \& Xu, X. (2012). Consumer acceptance and use of information technology: extending the unified theory of acceptance and use of technology. MIS Quarterly, 36(1), 157-178.

Wang, Y. X., Xue, X. L., \& Li, Y. (2013). A Critical Review on the Impact Factors of BIM Application. International Journal of Digital Content Technology and its Applications, 7(8), 616-624.

Widyawan, L. N., \& Santosa, P. (2017). Technology Readiness and Technology Acceptance Model in New Technology Implementation Process in Low Technology SMEs. International Journal of Innovation, Management and Technology, 8(2), 113-117. https://doi.org/10.18178/ijimt.2017.8.2.713

\section{Copyrights}

Copyright for this article is retained by the author(s), with first publication rights granted to the journal.

This is an open-access article distributed under the terms and conditions of the Creative Commons Attribution license (http://creativecommons.org/licenses/by/4.0/). 